\title{
HUMAN DIGNITY - OUR SUPREME CONSTITUTIONAL VALUE
}

\section{ISSN 1727-3781}

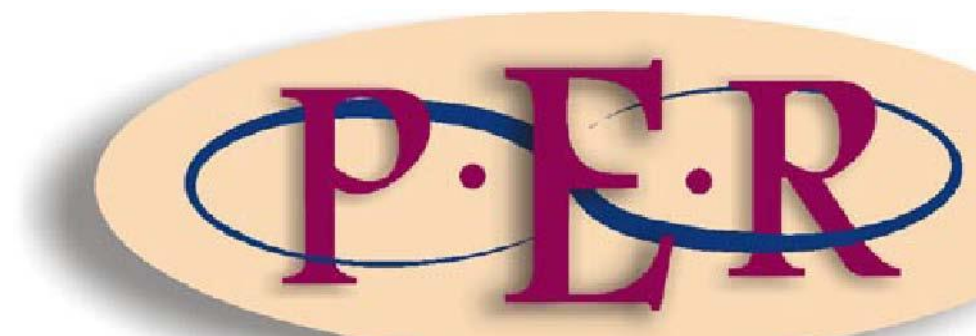

2001 VOLUME 4 No 1 


\title{
HUMAN DIGNITY - OUR SUPREME CONSTITUTIONAL VALUE ${ }^{1}$
}

\begin{abstract}
Nazeem MI Goolam ${ }^{2}$
University of South Africa

Everyone has inherent dignity and the right to have their dignity respected and protected. $^{3}$
\end{abstract}

\section{Introduction}

There can be little doubt that, as far as constitutional interpretation and statutory interpretation in general is concerned, South Africa is undergoing a transformation from a formal, positivistic vision of law to a substantive, natural law vision of law. ${ }^{4}$ And the single most significant factor in this transformation is the existence of constitutional values. For the first time in South Africa, courts (in particular the Constitutional Court) must decide cases on the basis of these values. It is therefore simply erroneous and naive to say that 'the Constitutional Court has been so fixated with the role of 'values' in the first year of its existence $^{5}$ and that the court is 'obsessed' with the role of 'values' ${ }^{6}$. Of these values, the three most fundamental in any open and democratic society are human dignity, equality and freedom. Amongst this trinity of values human dignity, it is submitted, finds pride of place. In sections $1,7,36^{7}$ and $39^{8}$ of South Africa's final constitution it takes primary mention. Section 1 provides:

The Republic of South Africa is one, sovereign democratic state founded on the following values:

(a) Human dignity, the achievement of equality and the advancement of human rights and freedoms...

1 Revised version of a paper delivered at the International Conference on Development in the Contemporary Constitutional State, Potchefstroom University, 2 - 3 November 2000. 2 BA LLB (University of Cape Town) MCL (International Islamic University, Malaysia. 3 S 10 of the Constitution of the Republic of South Africa, Act 108 of 1996. 4 Certainly not the cynical vision of "Rainbow Jurisprudence" put forward by Cockrell. See Cockrell 1996 SAJHR

1. 5 Supra at 7.6 Supra at 10.7 The limitation clause. 8 The interpretation clause. 
Elsewhere I have stated:

It is not insignificant that the value of human dignity does not appear either after the values of equality and freedom or between the value of equality and freedom. On the contrary, it is highly significant that human dignity appears before both equality and freedom because essentially, human rights law must serve the purpose of effectively protecting the human dignity of the members of any society. ${ }^{9}$

Some of the pertinent questions briefly addressed in this article are:

1) What does human dignity entail?

2) Is human dignity a right or a duty?

3) How should it be understood in a plural society such as ours?

4) What about the impact of modern technology on human dignity?

5) Is our understanding of the concept/value/idea of human dignity not too European/Western in nature? For example, the issue of gays and lesbians is a human rights and human dignity question in the West, while other cultures find homosexuality abhorrent and uncivilised.

6) Should we explore a religious and spiritual philosophy of human dignity?

These are some of the pertinent issues which, I believe, need to be carefully discussed in attempting to understand the concept/value/idea of human dignity in our multicultural country.

\section{What does human dignity entail?}

First, then, what does human dignity entail? Article $1^{10}$ of the 1949 German Constitution or Basic Law (Grundgesetz) provides:

9 Goolam 1997 SA PublicLaw 186.

10 Protection of human dignity. 
(1) The dignity of man shall be inviolable. To respect and protect it shall be the duty of all state authority.

(2) The German people therefore acknowledge inviolable and inalienable human rights as the basis of every community, of peace and of justice in the world.

In the original German the first sentence of article 1 (1) reads: "Die Würde des Menschen ist unantastbar." The word "Würde" may be translated as "worth" or "value." In the now well-known South African Constitutional Court decision of $S$ v Makwanyane Judge O'Regan expressed a similar view. According to her:

Recognising a right to dignity is an acknowledgement of the intrinsic worth of human beings: human beings are entitled to be treated as worthy of respect and concern. This right therefore is the foundation of many of the other rights that are specifically entrenched in ... [the Bill of Rights]. ${ }^{12}$

Referring to Kantian philosophical thought, Jones writes that dignity is "above all price and so admits of no equivalent". ${ }^{13}$ Commenting on the significance of the concept of human dignity in German constitutional jurisprudence. Donald Kommers states:

Germany's emphasis on dignity is nevertheless important, and for three reasons: First, the principle of human dignity makes normative demands on the state; second, it informs the scope and meaning of all the rights and guarantees of the Basic Law; and third, it is the source of the so-called objective value that the Federal Constitutional Court has inferred from the Basic Law's principles and structures. In short, the Constitutional Court envisions the Basic Law as a unified structure of objective principles and rights crowned by the master value of human

dignity. $^{14}$

11 S v Makwanyane 1995 (6) BCLR 665 (CC); S v Makwanyane 1995 (3) SA 391 (CC).

12 Supra at par 328.

13 Jones Kant's Principle of Personality 127; see also De Waal, Currie and Erasmus Bill of Rights Handbook 217.

14 July 1998, on receiving an honorary doctor of law degree from Ruprecht - Karl's University, Heidelberg, Germany. 
Elsewhere, commenting on the human dignity clause as the centre of Germany's scheme of constitutional values, the learned author writes:

In the view of the Federal Constitutional Court, this clause expresses the highest value of the Basic Law, informing the substance and spirit of the entire document. While encompassing all guaranteed rights, the concept of human dignity also includes a morality of duty that may limit the exercise of a fundamental right. ${ }^{15}$

Delivering the Third Bram Fischer Memorial Lecture ${ }^{16}$ in May 2000, the President of the Constitutional Court, Judge Arthur Chaskalson stated:

The affirmation of human dignity as one of the founding values of the Constitution is significant. The interim Constitution emphasised the values of democracy, freedom and equality. Although dignity is immanent in these values and in the rights entrenched in the interim Constitution's Bill of Rights, its role as a foundational value of the constitutional order was not acknowledged in specific terms until the adoption of the 1996 Constitution. Consistently with this, the 1996 Constitution now refers to the 'inherent dignity' of all people, thus asserting that respect for human dignity, and all that flows from it, as an attribute of life itself, and not a privilege granted by the state.

\section{$3 \quad$ Human dignity - right of duty?}

This leads to the second question, namely is human dignity merely a right - as section 10 declares -or is it not also a duty/an obligation/a responsibility? Indeed, a value - which human dignity is - implies that people are duty-bound to uphold it. Every human being has a responsibility to treat every other human being in a dignified and humane manner. Human dignity is therefore a universal human duty, a universal human responsibility. In this regard, the Universal Declaration of Human Responsibilities is highly instructive. Its preamble commences as follows: 
Whereas recognition of the inherent dignity and of the equal and inalienable rights of all members of the human family is the foundation of freedom, justice and peace in the world and implies obligations or responsibilities. ${ }^{17}$

Articles 1 and 2 - which fall under the heading Fundamental Principles for Humanity - of the Declaration read:

Article 1 Every person regardless of gender, ethnic origin, social status, political opinion, language, age nationality or religion has a responsibility to treat all people in a humane way.

Article 2 No person should lend support to any form of inhumane behaviour, but all people have a responsibility to strive for the dignity and the self-esteem of all others. $^{18}$

Indeed, non-Western philosophies - African, Asian and indigenous traditions - lay great emphasis on the obligations/responsibilities of an individual as compared with his/her rights. In this regard, it is apt to quote the words of one of the most dignified human beings of the past 100 years: Mohandas Gandhi. The Mahatma did not advocate individual rights in the Western sense. Rather, he advocated "dharma, an ethic of community, responsibility and loyalty." ${ }^{19}$ He said:

All rights to be deserved and preserved come from duty well done. Thus the very right to live accrues to us only when we do the duty of citizenship of the world. ${ }^{20}$

Dharma has been described or defined as:

...that which is established or firm, steadfast decree, statute, ordinance, law; usage, practice, customary observance or prescribed conduct, duty, right. Justice (often as a synonym of punishment); virtue, morality, religion, religious merit, good

17 Schmidt Grundpflichten 306.

18 lbid.

19 Ayoub "Asian Spiritual and Moral Values and Human Rights". 
works, ...according to the nature of anything, ... holding to the law, doing one's duty, ... nature, character, peculiar condition or essential quality, property, mark, peculiarity, ... sacrifice, $\ldots$ associating with the virtuous, ... devotion, $\ldots$ a bow ... ${ }^{21}$

It is this "ethic of community", this communal approach, this communitarianism which distinguishes the approach to human rights discourse - and thus the concept of human dignity - in African and non-Western societies from the liberal, individual-centred Western tradition. It is submitted that the Western emphasis on individual rights and freedoms is often to the detriment of the collectivity. ${ }^{22}$

As Judge Mokgoro so adequately explained in the Makwanyane ${ }^{23}$ decision, the spirit of ubuntu emphasises respect for human dignity. Metaphorically speaking, it expresses itself in umuntu ngumuntu ngabantu, describing the significance of group solidarity on survival issues so central to the survival of communities. The point is that we in South Africa, in Africa, should not - and cannot - rely solely on Western/European jurisprudence in attempting to understand the concept/value/idea of human dignity. After all, the past 500 years have seen arguably the worst and most horrendous violations of human rights and human dignity by western peoples on the non-western peoples of the world.

\section{Human dignity in a plural society - the notion of tolerance}

How, then, should human dignity be understood in a plural society such as ours? Paul Sieghart states that the hallmarks of a democratic society are "pluralism, broadmindedness and tolerance." ${ }^{24}$ If dignity is to be truly respected and protected - as provided for in section 10 of the South African Constitution - the notion of tolerance, labelled by UNESCO (United Nations Educational, Scientific and Cultural Organisation) as the endangered virtue demands broader understanding. A brief examination of UNESCO's 1995 Declaration on the Principles of Tolerance ${ }^{25}$ is appropriate. The document preceding the declaration, entitled A Global Quest for Tolerance, declares that

\footnotetext{
Traer Faith and Human Rights Support 131; see also Muzaffar Human Rights and the New World Order.

See Monier-Williams Sanskrit-English Dictionary 510; see also Domanski 2000 CILSA 248.

For a poetic communitarian critique of liberalism see Cranova 1999 Codicillus 41.

See $\mathrm{n} 8$ supra at par 308.

24 Sieghart International Law of Human Rights 784-791.
} 
tolerance has always been considered a moral virtue and that it is also the foundation of democracy and human rights. Tolerance is appreciation of diversity, the ability to live and let others live, the ability to adhere to one's convictions while accepting that others adhere to theirs and the ability to enjoy one's rights and freedoms without infringing on those of others. Intolerance in multi-ethnic, multi- religious or multicultural societies leads to violations of human rights, violence or armed conflict.

Article 1 of the Declaration is headed 'Meaning of Tolerance' and it is necessary, in the context of this paper, to reproduce its first two paragraphs, which state:

1.1 Tolerance is respect, acceptance and appreciation of the rich diversity of our world's cultures, our forms of expression and ways of being human. It is fostered by knowledge, openness, communication and freedom of thought, conscience and belief. Tolerance is harmony in difference. It is not only a moral duty, it is also a political and legal requirement. Tolerance, the virtue that makes peace possible, contributes to the replacement of the culture of war by a culture of peace.

1.2 Tolerance is not a concession, condescension or indulgence. Tolerance is, above all, an active attitude prompted by recognition of the universal human rights and fundamental freedoms of others. In no circumstance can it be used to justify infringements of these fundamental values. Tolerance is to be exercised by individuals, groups and states.

Article 4, which is devoted to education, states that education for tolerance should aim at countering influences that lead to fear and exclusion of others, and should help young people to develop capacities for independent judgment, critical thinking and ethical reasoning. 


\section{$5 \quad$ Human dignity in the age of technology}

The value of human dignity will, of course, impact not only on the other two values equality and freedom - in the trinity of fundamental democratic values but also on the manner in which the rights in the Bill of Rights is interpreted. One thinks of the right to life (including the beginning and end of life), issues relating to criminal justice, freedom of religion, and from a global perspective, the right to asylum. But, perhaps, the most pertinent question in this regard is: what about the protection of human dignity in the age of technology? How can human dignity be protected in the computer age or when considering the dramatic potential of modern gene technology, in vitro fertilization or other technical and scientific developments? Weeramantry, Vice-President of the International Court of Justice, has further asked: "What are the technologies that erode this high recognition of human dignity through their impact upon the human body?" ${ }^{26}$

Judge Weeramantry is of the view that research on the human body for therapeutic and preventive purposes must always go ahead. He warns, however, that as more knowledge is acquired, new possibilities open up the use of that knowledge for unethical purposes or for purposes the ethical value of which is debatable. ${ }^{27}$ Therefore, he says, 'constant vigilance is required to ensure that new advances in medical technology are kept within ethical guidelines'. The learned author lists a host of possible sources of the denigration of human dignity by scientific power. His comprehensive list of sources includes, inter alia, foetal experimentation, human experimentation, embryo transplantation, in vitro fertilization, foetus farms, sperm and ova banks, selective breeding, genetic structuring of humans, sex preselection, organ transplants, enzyme engineering, sale of human tissue, euthanasia techniques, computerized regimentation of society and data bank infringements of privacy.

\section{$6 \quad$ Exploring a philosophy of human dignity}

Finally, a word on the origin of the idea/concept/value of human dignity. The first draft of article 1 of the German Grundgesetz produced by the Herrenchiemsee Conference 
stated that "the dignity of man is founded upon eternal rights with which every person is endowed by nature." The main parties to the conference agreed that human dignity is anterior to the state and thus transcendental. However, the Western individual-centred human rights paradigm views the individual as the ultimate measure of all things. There is thus no notion of the human being subordinating him/herself to a Transcendental Reality which, in fact, establishes the parameters for the exercise of one's rights. Seen in this light, is there not a need to explore a philosophy of human dignity having its roots in the moral, theological and spiritual traditions of the world? In the words of a leading scholar, Chandra Muzaffar: ${ }^{28}$

[W]hether one articulates rights or upholds responsibilities, shouldn't they be guided by universal moral and spiritual values which would determine the sort of rights we pursue and the type of responsibilities we fulfil. Without a larger spiritual and moral framework, which endows human endeavour with meaning and purpose, with coherence and unity, wouldn't the emphasis on rights per se lead to moral chaos... What are human rights if they are not related to more fundamental questions about the human being? Who is the human being? Why is the human being here? Where does the human being go from here? How can one talk of the rights of the human being without a more profound understanding of the human being him[her]self? ${ }^{29}$

\section{Muzaffar declares:}

The great challenge before us is to develop this vision of human dignity culled from our religious and spiritual philosophies into a comprehensive charter of values and principles, responsibilities and rights, roles and 
relationships acceptable to human beings everywhere. To do this we should first distinguish what is universal and eternal within our respective traditions from what is particularistic and contextual. ${ }^{30}$

\section{The essence of human dignity in South Africa today}

I believe that the essence of human dignity in our country today was succinctly summed up by Judge Arthur Chaskalson in the Third Bram Fischer Memorial Lecture, when he said:

As an abstract value, common to the core values of our Constitution, dignity informs the content of all the concrete rights and plays a role in the balancing process necessary to bring different rights and values into harmony. It too, however, must find its place in the constitutional order. Nowhere is this more apparent than in the application of the social and economic rights entrenched in the Constitution. These rights are rooted in respect for human dignity, for how can there be dignity in a life lived without access to housing, health care, food, water or in the case of persons unable to support themselves, without appropriate assistance. In the light of our history the recognition and realisation of the evolving demands of human dignity in our society - a society under transformation is of particular importance for the type of society we have in the future. ${ }^{31}$ 


\section{Bibliography}

Ayoub "Asian Spiritual and Moral Values and Human Rights"

Ayoub MM "Asian Spiritual and Moral Values and Human Rights" Paper delivered at the International Conference on Rethinking Human Rights 6-7 December 1994 Kuala Lumpur

Chaskalson 2000 SAJHR

Chaskalson A "Human Dignity as a Foundational Value of our Constitutional Order" 2000 SAJHR 193

Cockrell 1996 SAJHR

Cockrell A "Rainbow Jurisprudence" 1996 SAJHR 1

Cranova 1999 Codicillus

Cranova A "The communitarian critique on liberalism" 1999 Codicillus XXXX No 241

De Waal Currie and Erasmus Bill of Rights Handbook 217

De Waal J Currie I and Erasmus G The Bill of Rights Handbook $2^{\text {nd }}$ ed (Juta Cape Town 1999)

Domanski 2000 CILSA 248

Domanski A "Stemming the blood - dimmed tide of lawlessness: the rediscovery of duties" 2000 CILSA XXXIII 245

Goolam 1997 SA Public Law

Goolam NMI "The interim Constitution, the working drafts and South Africa's new Constitution - some observations" 1997 SA Public Law 186

Jones Kant's Principle of Personality Jones HE Kant's Principle of Personality (University of Wisconsin Press Madison 1971) 
Monier-Williams Sanskrit-English Dictionary 510

Monier-Williams M Sanskrit-English Dictionary (Oxford 1899)

Muzaffar Human Rights and the New World Order

Muzaffar C Human Rights and the New World Order (Just World Trust Penang 1993) 182

Muzaffar "From Human Rights to Human Dignity"

Muzaffar C "From Human Rights to Human Dignity" Paper delivered at the International Conference on Rethinking Human Rights 6-7 December 1994 Kuala Lumpur

Schmidt Grundpflichten

Schmidt TI Grundpflichten (Nomos Baden-Baden 1999)

Kommers Constitutional Jurisprudence

Kommers DP The Constitutional Jurisprudence of the Federal Republic of Germany $2^{\text {nd }}$ ed

(Duke University Press Durham NC 1997) 620

Sieghart International Law of Human Rights

Sieghart P The International Law of Human Rights (Clarendon Press Oxford 1983) 569

Traer Faith and Human Rights Support

Traer R Faith and Human Rights Support in Religious Traditions for a Global Struggle (Georgetown University Press Washington 1991) 216

Weeramantry Justice without Frontiers

Weeramantry CG Justice without Frontiers: Protecting Human Rights in the Age of

Technology (Kluwer Law International The Hague 1998) 648 


\section{Register of acts}

Constitution of the Republic of South Africa Act 108 of 1996

Grundgesetz für die Bundesrepublik Deutschland (GG) vom 23.

Mai 1949

\section{Register of cases}

S v Makwanyane 1995 (3) SA 391 (CC)

$S$ v Makwanyane 1995 (6) BCLR 665 (CC) 